\title{
Role of external factors in the evolution of the ozone layer and stratospheric circulation in 21 st century
}

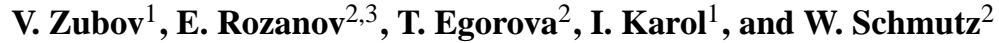 \\ ${ }^{1}$ Main Geophysical Observatory, Saint-Petersburg, Russia \\ ${ }^{2}$ Physikalisch-Meteorologisches Observatorium, World Radiation Center, Davos Dorf, Switzerland \\ ${ }^{3}$ Institute for Atmospheric and Climate Science ETH, Zurich, Switzerland
}

Correspondence to: T. Egorova (t.egorova@pmodwrc.ch)

Received: 24 September 2012 - Published in Atmos. Chem. Phys. Discuss.: 30 October 2012

Revised: 20 March 2013 - Accepted: 15 April 2013 - Published: 7 May 2013

\begin{abstract}
The chemistry-climate model (CCM) SOCOL has been used to evaluate the contributions of the main anthropogenic factors to the simulated changes of ozone and stratospheric dynamics during the 21 st century. As the main anthropogenic factors we consider the atmospheric concentration of the greenhouse gases (GHG), ozone depleting substances (ODS) and sea surface temperature and sea ice (SST/SI). The latter is considered here as an independent factor because the majority of the CCMs prescribe its evolution. We have performed three sets of "time slice" numerical experiments for the years 2000, 2050, and 2100 taking into account all factors separately and all together. The total column ozone increase during the first half of the 21st century is caused by the ODS, especially in the middle and high latitudes of both hemispheres. In the tropics and the extra tropical region of the Northern Hemisphere $(\mathrm{NH})$ the SST/SI forcing plays a very important role in the evolution of atmospheric ozone during the second half of the 21st century. The GHG affect the temperature and ozone mainly in the upper stratosphere and in the lower stratosphere of the high latitudes of the Southern Hemisphere (SH). In the lower tropical stratosphere of the $\mathrm{NH}$, the long-term changes of the temperature, zonal wind and the meridional circulation are controlled mainly by the SST/SI. The strong contribution of the SST/SI to the ozone and circulation changes in the future implies that some differences between the results by different CCMs could be caused by the applied SST/SI rather than by the CCM's deficiencies. We suggest taking this issue into account for the planning of the future model evaluation campaigns.
\end{abstract}

\section{Introduction}

During the last decade substantial efforts of the atmospheric research community were focused on the modeling of the global stratospheric ozone and climate changes throughout the 21st century caused by the anthropogenic factors (SPARC CCMVal, 2010, Chapter 9; WMO, 2011, Chapter 4) using chemistry-climate models (CCM). A typical $\mathrm{CCM}$ consists of a general circulation model and a threedimensional global chemistry-transport model. These model components interact by exchanging the global fields of gas species and dynamics parameters. Thus, according to their formulations CCMs inherently take into account the main feedbacks between climate and composition existing in the real atmosphere (Morgenstern et al., 2010). To enhance the confidence of the projections most of the state-of-the-art CCMs have been evaluated and improved using the processoriented evaluation procedures in the framework of the comprehensive SPARC Chemistry-Climate Model validation activities - CCMVal-1 and CCMVal-2 (Eyring et al., 2006; SPARC CCMVal, 2010).

The main anthropogenic factors affecting the long-term variability of stratospheric ozone, temperature and circulation of the atmosphere can be divided into three groups: (1) increasing greenhouse gas concentrations $\left(\mathrm{GHG}-\mathrm{CO}_{2}\right.$, $\mathrm{CH}_{4}$, and $\mathrm{N}_{2} \mathrm{O}$ ) as the result of economic development (IPCC, 2001, 2007); (2) the decline of ozone depleting substances (ODS) resulting from implementation of the Montreal Protocol (WMO, 2007); and (3) the changes of sea surface temperature and the sea ice parameters (SST/SI). The latter factor is the direct consequence of the GHG influence, 
but the majority of the CCMs involved in the assessment of the ozone layer evolution exploit SST/SI distribution prescribed from atmosphere-ocean general circulation models (Morgenstern et al., 2010). Therefore, the SST must be considered as an external factor because SOCOL and the majority of models participating in CCMVal have no interactive ocean.

The atmospheric composition and climate changes in the 21 st century simulated with different CCMs have been presented recently in a number of publications (e.g., Austin and Wilson, 2010; Austin et al., 2010; Gettelman et al., 2010; Zubov et al., 2011). Main conclusions and findings of these studies have been summarized in two assessments (SPARC CCMVal, 2010; WMO, 2011). According to these publications the process of the ozone layer recovery caused by the decreasing halogen loading in the atmosphere will proceed at different rates in the various atmospheric regions and depends also on the temperature and circulation changes. It is concluded that in the year 2100 the simulated total column ozone will reach nearly its 1960 year ("unperturbed") values in the southern polar latitudes and Antarctic ozone "hole" will almost disappear. In the middle and high latitudes of the Northern Hemisphere $(\mathrm{NH})$ and the middle latitudes of the Southern Hemisphere (SH) the total column ozone in the year 2100 will exceed their "unperturbed" state, while the tropical ozone layer will not recover even in 2100. It should be noted that the above mentioned differences in the future ozone behavior occur mainly in the lower stratosphere/upper troposphere and are strongly model dependent, while in the upper stratosphere all CCMs simulate almost identical ozone recovery during the next $100 \mathrm{yr}$.

It is of substantial interest to evaluate the contributions of the main external factors to the total tendencies of the ozone layer and the dynamics throughout the 21 st century and on the other hand to establish what role is played by the basic physical and chemical processes such as heating/cooling, photochemical loss/production and the species transport, which are internal for climate system. To address the latter problem Oman et al. (2010a) applied multi-linear regression analysis (MLR) technique to estimate the contributions of the photochemical loss/production processes and the temperature tendency to the simulated ozone changes in the upper stratosphere. However, the MLR method has not been applied to the analysis of the main anthropogenic factors contribution simulated with CCMs. There are other limitations regarding the applicability of the MLR analysis to the attribution of the ozone changes in the middle and lower stratosphere discussed in detail by Oman et al. (2010a, b). This motivates to exploit different approaches because these regions play crucial role in the understanding of the longterm total column ozone tendency in the CCMs model projections.

From our point of view, the evaluation of the external factors affecting the long-term atmospheric changes has some priority against the internal physical and chemical processes effects, because the external forcings constitute the ultimate cause of the all atmospheric long-term changes in the future. They operate in the atmosphere via the acceleration or suppression of the internal physical and chemical processes in the climate system. Thus the study of the atmospheric response to the external anthropogenic factors is more instructive than the attribution to the internal processes such as temperature changes, photochemical loss/production and transport (e.g., Oman et al., 2010a), because these factors are independent on the atmospheric state. Understanding of the main driving factors is very important for further model improvements. It was mentioned in several publications (e.g., Eyring et al., 2010; Charlton-Perez et al., 2010; Strahan et al., 2011) that there is a substantial scatter among CCMs in the projection of the future ozone layer, however, the reasons for this uncertainty have not been clearly identified. As it was shown by Charlton-Perez et al. (2010), the ambiguity of the future ozone evolution depends mainly on the model and scenario uncertainties, while the contribution of the internal model variability is small. There is no strong evidence whether this is caused by some model deficiencies in the representation of the chemical, dynamical and transport processes or by the differences in the prescribed external forcing. It seems that the prescribed evolution of GHG and ODS cannot be the cause of the inter model scatter in the ozone projections because all CCMs that participated in CCMVal-2 activity applied almost identical scenarios (Morgenstern et al., 2010). However, it is not the case for the future SST/SI distributions taken from different models participated in IPCC AR4 assessment (IPCC, 2007), which are characterized by substantially different magnitude and pattern of the future climate change. The application of different SST/SI data sets to estimate the uncertainty of the future ozone behavior is important. But it is also important to understand and attribute the causes of the uncertainty (e.g., Charlton-Perez et al., 2010). For the CCM community this is a crucial problem, because if the prescribed SST/SI is responsible for large scatter among model predictions any model improvements would not help to reduce the scatter.

In this paper we estimate the contribution of the main anthropogenic external factors to the 21 st century evolutions of the ozone layer, temperature and circulation of the stratosphere exploiting CCM SOCOL (version 2.0), which participated in the CCMval-1/2 model intercomparison campaigns (Eyring et al., 2007; SPARC CCMVal, 2010). To avoid the shortcoming of the MLR attribution approach in the middle and lower stratosphere, the method of "idealized" experiments is used (e.g., Kodama et al., 2007). According to this method we have performed one reference experiment changing all considered factors together and three additional ensemble simulations taking into account long-term evolution of either SST/SI or GHG or ODS separately. For the latter experiments two external factors are fixed on the present-day level. Comparison of the results of the numerical experiments allows us to evaluate the contribution of each external factor 
to the evolution of the ozone layer, temperature and circulation over 21 st century.

In Sect. 2 the model description and design of the numerical experiments are presented. Section 3 contains the analysis of the simulation results. The summary and conclusions of the paper are in Sect. 4.

\section{Model design and description of numerical experiments}

\subsection{Model description}

The simulations discussed below have been performed using the global three-dimensional CCM SOCOL version 2.0. The model has been developed at the PMOD/WRC (Davos, Switzerland) in collaboration with ETH (Zurich, Switzerland) and Voeikov Main Geophysical Observatory (St. Petersburg, Russia) (Egorova et al., 2005). The CCM SO$\mathrm{COL}$ consists of the middle atmosphere version of the European Center/Hamburg Model (MA-ECHAM4) (Manzini et al., 1997) and the three-dimensional chemistry-transport model (CTM) for the Evaluation of Ozone Trends (MEZON) (Egorova et al., 2003). Vertical model structure includes 39 levels of a hybrid sigma/pressure coordinate system and extends from the surface up to $0.01 \mathrm{hPa}(\sim 80 \mathrm{~km})$. The horizontal model resolution $\left(3.75^{\circ} \times 3.75^{\circ}\right)$ is defined by the horizontal spectral truncation of the MA-ECHAM4 (T30).

The time-space distributions of the 45 trace gases from the major atmospheric groups are calculated by the CTM MEZON taking into account 118 gas phase reactions, 33 photolytic reactions, and 16 heterogeneous reactions. The space-resolved transport of the model species is computed using the hybrid advection scheme (Zubov et al., 1999). Main modules of the CCM SOCOL (MEZON and MA-ECHAM4) are exchanging meteorological and chemical species fields every $2 \mathrm{~h}$. The mixing ratios of ozone, methane, nitrous oxide, chlorofluorocarbons, and water vapor are passed from MEZON to MA-ECHAM4, and the global three-dimensional distributions of temperature, water vapor concentration, and zonal, meridional, and vertical components of wind velocity are transferred from MA-ECHAM4 to MEZON. The chemical transformations of the water vapor are treated in the MEZON, while the water vapor tendencies related to physical processes are calculated in MA-ECHAM4. Thus, the CCM SOCOL inherently accounts for the interactive properties and basic feedbacks between dynamical, transport, photochemical, and radiative processes. The original description of SOCOL is presented more thoroughly in Egorova et al. (2005). The CCM SOCOL was applied to investigate the influence of the shortwave solar irradiance variability during the 11-year solar cycle on the composition and dynamics of the middle and lower atmosphere (Egorova et al., 2004) and to analyze the additional heating of the polar lower stratosphere from galactic cosmic rays and its plausible impact on atmospheric ozone, temperature, and circulation (Zubov et al., 2005, 2006). To verify and increase the confidence of the model results the CCM SOCOL participated in the International Chemistry-Climate Model Validation Activity (CCMval-1,2) of the Stratospheric Processes and Their Role in Climate (SPARC) program. CCMval-1, 2 are the most extensive CCMs intercomparison and validation campaigns in the recent decade (Eyring et al., 2007; SPARC CCMVal, 2010). The comparisons and verifications performed in the framework of CCMval-1 provided an opportunity to put together the new improved version of CCM SOCOL version 2.0 (Schraner et al., 2008). The results published in the final CCMval-2 report (SPARC CCMVal, 2010) allow us to conclude that CCM SOCOL 2.0 is comparable to most of the other stratospheric CCMs.

\subsection{Description of numerical experiments}

To attribute the ozone and atmospheric dynamics changes over the 21st century, we have performed three sets of time slice numerical experiments with the CCM SOCOL 2.0, for the 2000, 2050, and 2100 conditions, respectively. As driving factors we consider long-term evolution of the ODS, GHG and SST/SI quantities (Table 1).

The mixing ratio of ODSs in the lower troposphere evolves according to the World Meteorological Organization (WMO) A1 scenario (WMO, 2007). The atmospheric mixing ratio changes of the main GHGs $\left(\mathrm{CO}_{2}, \mathrm{CH}_{4}\right.$ and $\mathrm{N}_{2} \mathrm{O}$ ) are taken from the "most plausible" SRES scenario A1B IPCC (IPCC, 2001, 2007). The SST/SI fields for the 21 st century are adopted from the relevant simulations of the ECHAM5/MPIOM model (Jungclaus et al., 2006) using the SRES A1B IPCC scenario for the GHG long-term variations. Therefore, the SST/SI and GHG fields utilized in our numerical runs with the CCM SOCOL 2.0 are consistent.

Each experiment set includes four $20 \mathrm{yr}$ model runs (excluding the set for the $2000 \mathrm{yr}$ conditions). The first run (FULL) takes into account the impact of all external factors (i.e., evolutions of the GHG, ODS and SST/SI). The second run (GHG) simulates the influence of the GHG longterm changes only (ODS and SST/SI represent the year 2000 conditions). The third run (ODS) represents the influence of the ODS long-term evolution (GHG and SST/SI represent the year 2000 conditions). Finally, the fourth run (SST/SI) takes into account only the SST/SI long-term changes keeping GHG and ODS at the year 2000 level. The experiment set of the 2000 year conditions includes only one run (FULL) and all considered forcings are prescribed for the year 2000. Table 1 presents the summary of the undertaken model experiments.

Each $20 \mathrm{yr}$ time slice model run consists of $10 \mathrm{yr}$ spinup calculations, which is necessary for the adaptation of the chemical composition and dynamics of the model atmosphere to the specific boundary conditions. Then, the two year long run is repeated five times stating from the same 
Table 1. The list of the numerical experiments performed with CCM SOCOL 2.0. (Bold font marks the factor/year, in which contribution is studied by an experiment).

\begin{tabular}{lccc}
\hline & \multicolumn{3}{c}{ Factor/scenario/year } \\
\cline { 2 - 4 } Experiment & GHG - A1B & ODS - A1 & SST/SI - A1B \\
\hline FULL - 2000 & 2000 & 2000 & 2000 \\
FULL - 2050 & 2050 & 2050 & 2050 \\
FULL - 2100 & 2100 & 2100 & 2100 \\
GHG - 2050 & $\mathbf{2 0 5 0}$ & 2000 & 2000 \\
GHG - 2100 & $\mathbf{2 1 0 0}$ & 2000 & 2000 \\
ODS - 2050 & 2000 & $\mathbf{2 0 5 0}$ & 2000 \\
ODS - 2100 & 2000 & $\mathbf{2 1 0 0}$ & 2000 \\
SST/SI - 2050 & 2000 & 2000 & $\mathbf{2 0 5 0}$ \\
SST/SI - 2100 & 2000 & 2000 & $\mathbf{2 1 0 0}$ \\
\hline
\end{tabular}

initial conditions (the end of spin-up run) to generate five ensemble members using a slightly (within $\pm 0.01 \%$ ) changed $\mathrm{CO}_{2}$ mixing ratio unique for each run. We suppose that the applied scheme of the ensemble generation provides a higher degree of independence for the ensemble terms against the ensemble generation way based on the consecutive calculation. The ensemble approach allows us to estimate the natural variability of the model atmosphere and to define the statistical significance of the atmospheric responses to the considered external forcings against the background interannual model variability. The level of the significance is estimated by Student's $t$ test (von Storch and Zwiers, 2001). A comparison of the model run results is used to estimate the contribution of external factors to the evolution of the ozone layer, temperature and circulation of the stratosphere throughout 21 st century. For example, the difference between the outputs of "GHG-2050" and "FULL-2000" runs (Table 1) elucidates the role of the GHG factor in the atmospheric changes over the first half of the current century (from 2000 to 2050).

On the other hand, some interaction between the factors can exist. It means that the influence of one factor on the atmospheric changes depends on whether other factors operate together with it or not. Particularly, this dependency leads to nonequivalence between the total effect (FULL) of all factors and the sum of the separate effects (GHG + ODS + SST/SI) of the factors taken separately for the same time period. The residual term (RES) can be then introduced as

$\mathrm{RES}=\mathrm{FULL}-(\mathrm{GHG}+\mathrm{ODS}+\mathrm{SST} / \mathrm{SI})$.

The RES value can be calculated for all model cells and for each time step of the runs according to this equation. The magnitude and sign of the RES term allow us to find the areas of the atmosphere where the interplay between factors enhances or compensates the combined effect. However, the interpretation of the results depends on the signs of the FULL and cumulative (GHG + ODS + SST/SI) effects.
For example when the FULL and GHG + ODS + SST/SI effects have the same signs the enhancement correspondents to a case when RES and FULL have the same signs $(|\mathrm{FULL}|>|\mathrm{GHG}+\mathrm{ODS}+\mathrm{SST} / \mathrm{SI}|)$, and the compensation to a case when RES and FULL have different signs, $(\mid$ FULL $|<|$ GHG + ODS + SST/SI $\mid)$.

In the discussions of the model results presented below we analyze not only the FULL, GHG, ODS and SST/SI impacts on the atmosphere during the 21st century, but also the relevant values of the RES term. We estimate the statistical significance of the RES term and find the atmospheric regions in which this term cannot be masked by the interannual variability of the model atmosphere.

\section{Results}

The main external factors (GHG, ODS, SST/SI) affect the composition and dynamics of the atmosphere by a multitude of the physical and chemical mechanisms: an additional heating and cooling of the atmospheric air and surface, changes of the gas-phase and heterogeneous chemical reaction rates, changes of the atmospheric circulation followed by alteration of the gas transport and others. However, here we do not present the detailed analysis of all mechanisms paying main attention to the relative contributions of the external factors to the atmospheric parameter evolution over 21 st century.

The zonal-mean annually averaged ensemble-mean changes of temperature from 2000 to 2100 due to the influence of the ODS, GHG, SST/SI factors and their combination (FULL) are presented in Fig. 1. Figure 1b shows that GHG increase constitutes the main contribution to the cooling in the upper stratosphere. In this case the cooling over Antarctica is much more pronounced because the additional GHG enhance the radiative exchange of the atmospheric layers with a very cold surface of the Antarctic. The contribution in the temperature changes by the adiabatic expansion cooling from vertical motions is not substantial (Fig. 1c). Below $20 \mathrm{hPa}$ the SST/SI factor plays dominant role in the long-term temperature changes, especially in the tropics and in the $\mathrm{NH}$. Convective processes redistribute ocean warming vertically (see Olsen et al., 2007; Rind et al., 2002) leading to a pronounced (up to $8 \mathrm{~K}$ ) temperature rise in the upper tropical troposphere followed by the tropic/extratropic temperature gradient increase, acceleration of the extra-tropical jets (see also below), intensification of the Brewer-Dobson circulation (BDC). These results are close to the temperature response obtained by Rind et al. (2002) in set of the idealized experiments with GISS GCMAM model $\left(2 \times \mathrm{CO}_{2}\right.$, artificial SST/SI changes). More intensive upward motions in the lower BDC branch produces pronounced cooling due to adiabatic extension of the rising air (Fig. 1c). The SST/SI variations are also responsible for the additional heating in the extra tropical regions of the $\mathrm{NH}$. The decline of ODS concentration leads to the ozone increase followed by 

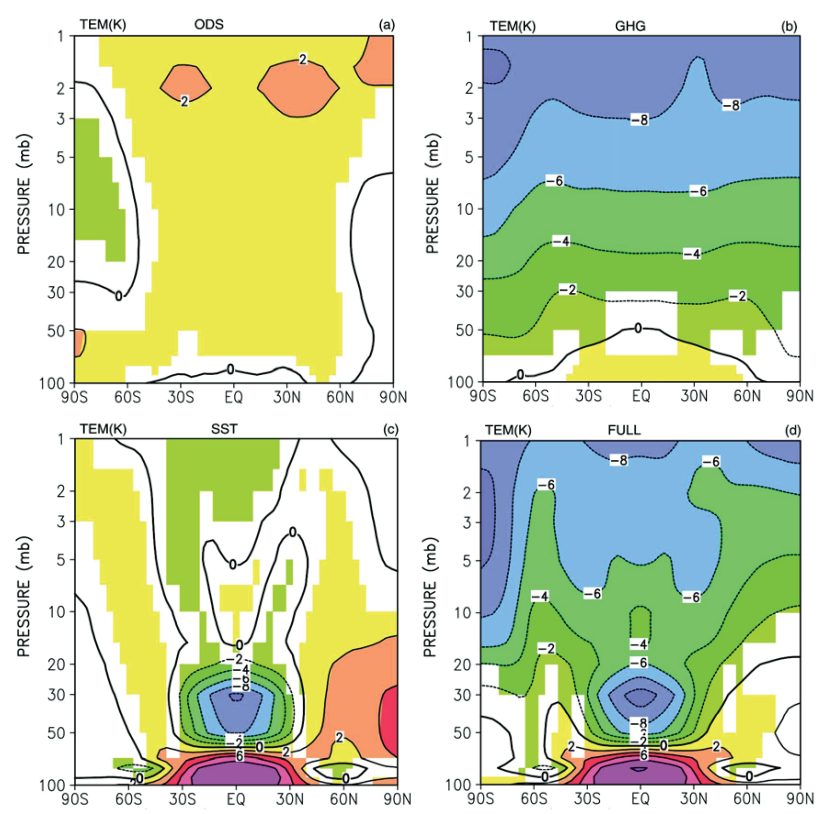

Fig. 1. Zonal, annual and ensemble mean changes of the temperature (K) from 2000 to 2100 caused by (a) ODS; (b) GHG; (c) SST/SI; (d) all factors (ODS, GHG, and SST/SI). Color pattern indicates the regions where the changes are judged statistically significant at or better than $5 \%$ level. Positive changes are shown in reddish colors while small or negative changes are colored in blue/violet.

a small heating, which partially compensates GHG induced cooling in the stratosphere. The lower stratosphere over the South Pole is an exception because the ODS induced heating exceeds the GHG cooling values there.

The zonal and annual-mean changes of the zonal wind velocity from 2000 to 2100 are presented in Fig. 2. In the upper stratosphere the ODS and GHG produce some acceleration of the westerlies in the middle latitudes of the both hemispheres. The SST/SI factor has quite different effects on the zonal wind in the $\mathrm{SH}$ and $\mathrm{NH}$, which consist of the eastward wind acceleration in the high and middle latitudes of the SH (except polar lower stratosphere) and deceleration in the high and middle latitudes of the NH. In the lower stratosphere the SST/SI forcing is mostly responsible for the zonal wind changes. The comparison of Fig. $2 \mathrm{c}$ and d shows that the SST/SI weaken the westerly wind over the middle and high latitudes of the $\mathrm{SH}$ and $\mathrm{NH}$ and substantially strengthens both subtropical jets extending their upper flanks in a vertical direction. Such changes of the subtropical jets enhance penetration and dissipation of waves in the lower stratosphere leading to an intensification of the BDC (Rind et al., 2002; Deckert and Dameris, 2008; Garcia and Randel, 2008; Calvo and Garcia, 2009; McLandress and Shepherd, 2009; Shepherd and McLandress, 2011). Additional warming of the polar lower stratosphere caused by the ODS forcing (see Fig. 1a) also contributes to the statistically signifi-
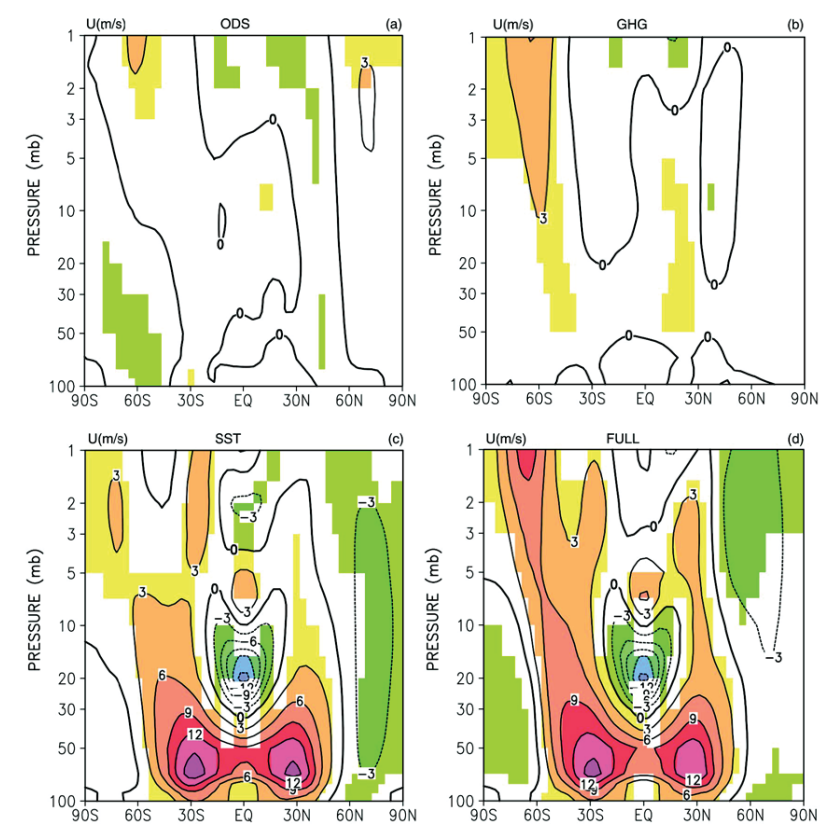

Fig. 2. Zonal, annual and ensemble mean changes of the zonal wind $\left(\mathrm{m} \mathrm{s}^{-1}\right.$ ) from 2000 to 2100 caused by (a) ODS; (b) GHG; (c) SST/SI; (d) all factors (ODS, GHG, and SST/SI). Color pattern indicates the regions where the changes are judged statistically significant at or better than $5 \%$ level. Positive changes are shown in reddish colors while small or negative changes are colored in blue/violet.

cant deceleration of the polar-night jet over Antarctica (see Fig. 2a).

As shown in Fig. 3, the decline of the halogen loading (ODS factor) plays a major role in the ozone increase in the entire upper stratosphere and in the lower stratosphere of the southern high latitudes (Fig. 3a). The ODS factor is important over the poles, but in the tropics of the upper stratosphere the GHG forcing is responsible for about a half of the ozone mixing ratio increase (see Fig. 3a and b). Below $20 \mathrm{hPa}$ the SST/SI forcing is the main driver of the ozone long-term evolution in the NH. Strengthening of the Brewer-Dobson circulation mentioned earlier caused by SST effects produces substantial ozone decrease in the tropics due to intensified upwelling of the tropospheric air with rather low ozone mixing ratio, and its additional accumulation over the northern extra-tropics (Fig. 3c). Li et al. (2009) showed the mentioned above ozone decline can be explained by the changes of ozone transport (Li et al., 2009, Fig. 2a, b and f).

Zonal-mean monthly total column ozone changes from 2000 to 2100 are illustrated in Fig. 4. Figure $4 \mathrm{a}$ and c show that the long-term column ozone changes are determined mainly by the ODS and SST/SI factors. The ODS decline leads to the total column ozone increase over all latitudes with the maximum of growth in the Antarctic ozone "hole" region and the minimum in the tropics. The SST/SI contribution to the total column ozone tendency over 21 st 

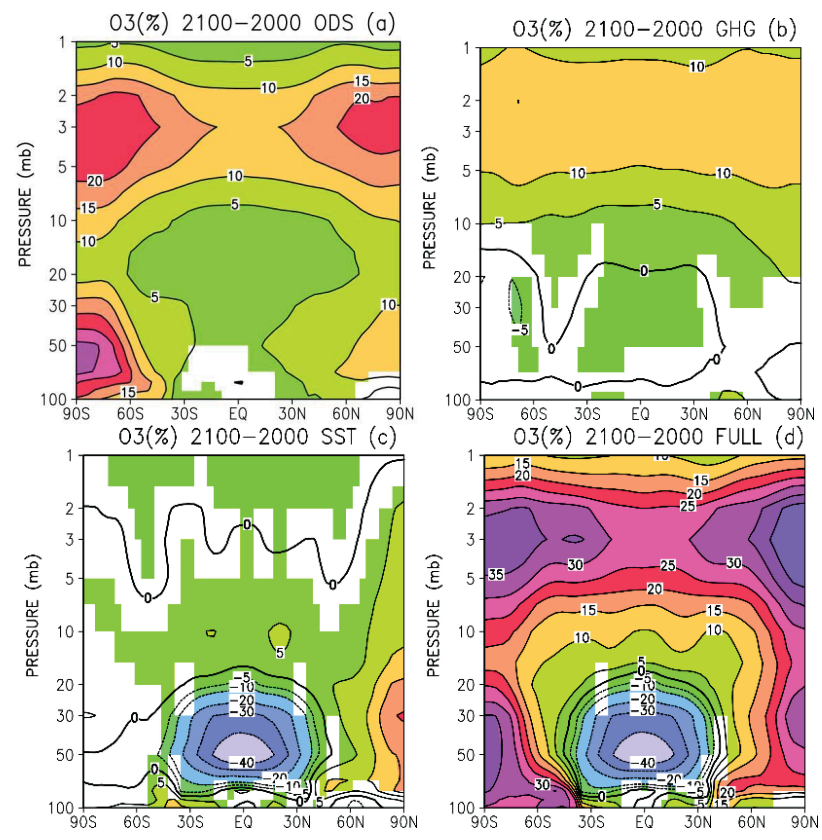

Fig. 3. Zonal, annual and ensemble mean changes of the ozone mixing ratio (\%) from 2000 to 2100 caused by (a) ODS; (b) GHG; (c) SST/SI; (d) all factors (ODS, GHG, and SST/SI). Color pattern indicates the regions where the changes are judged statistically significant at or better than $5 \%$ level. Positive changes are shown in reddish colors while small or negative changes are colored in blue/violet.

century is the most pronounced in the tropics and substantial in the extra-tropical latitudes. The influence of the GHG factor on the column ozone variations during the century is rather small, except the lower south polar stratosphere, where the GHG induced cooling slightly increases the area of the Antarctic ozone hole.

The zonal mean RES term (see Eq. 1) is presented in Fig. 5 for the annual mean temperature, zonal wind and ozone concentration changes as well as for the monthly mean total column ozone changes during the 21 st century. The interaction between the factors (RES term) leads to the polar stratosphere warming in the $\mathrm{SH}$ for the 21 st century. In agreement with these temperature changes, the eastward zonal wind velocities of the polar stratosphere are weaker in FULL experiment in comparison with the sum of the relevant wind velocity changes of GHG, ODS and SST/SI experiments. The statistical significance of the RES term for the temperature and zonal wind velocity changes are not very high (less than $95 \%$ for the most of the atmosphere) while the RES term values for the column ozone variations are statistically significant in the lower polar stratosphere. The interactions among the ODS, GHG and SST/SI factor over these areas lead to the acceleration of the ozone recovery, which is the most pronounced in austral summer and autumn.

It is of interest to evaluate the timing of the ozone and dynamics changes throughout the 21 st century. Comparison of
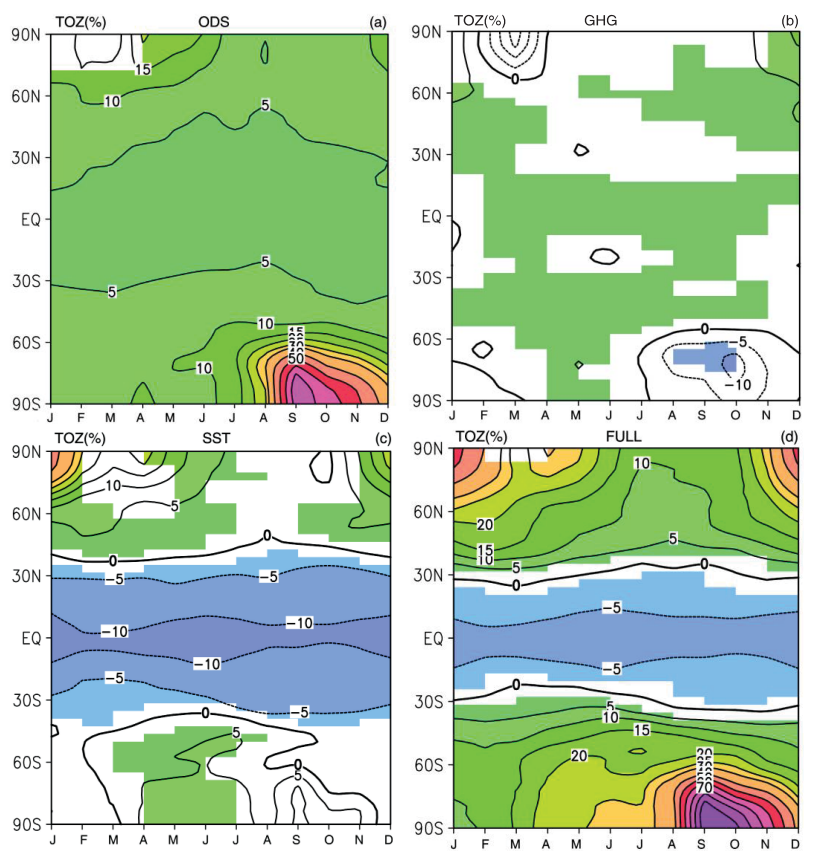

Fig. 4. Zonal and ensemble mean changes of the total column ozone (\%) from 2000 to 2100 caused by (a) ODS; (b) GHG; (c) SST/SI; (d) all factors (ODS, GHG, and SST/SI). Color pattern indicates the regions where the changes are judged statistically significant at or better than $5 \%$ level. Positive changes are shown in reddish colors while small or negative changes are colored in blue/violet.

the model runs for the years 2000, 2050 and 2100 allows us to evaluate these changes separately for the first and for the second half of the 21 st century. Figure 6 presents the zonally averaged annual mean changes of the zonal wind velocity (Fig. 6a) and monthly averaged total column ozone changes (Fig. 6c) from 2000 to 2050 under FULL forcing conditions. Figure $6 \mathrm{~b}$ and $\mathrm{d}$ illustrate changes in these variables for the time period from 2050 to 2100 . From Fig. 6a and b, we can conclude that the main changes in the stratospheric dynamics occur in the second half of the 21st century and can be attributed to the SST/SI forcing influence (see Fig. 2c and d). SST/SI factor also has dominant contribution to the deceleration of the stratospheric westerly winds to the north of $60^{\circ} \mathrm{N}$ from 2000 to 2050 (Fig. 6a). Figure 6c and d display the total column ozone changes in the 21 st century under FULL forcing condition and reveal that it increases over all latitudes in the first half of the century. This increase is much more pronounced at the middle and high latitudes of both hemispheres and depends mainly on the removal of ODS (compare Figs. 6c and 4a). In the second half of the century the column ozone changes are controlled by the SST/SI. The SST driven circulation changes are so strong in the tropical lower stratosphere that the resulting ozone depletion completely compensates ozone increases caused by ODS reduction. 

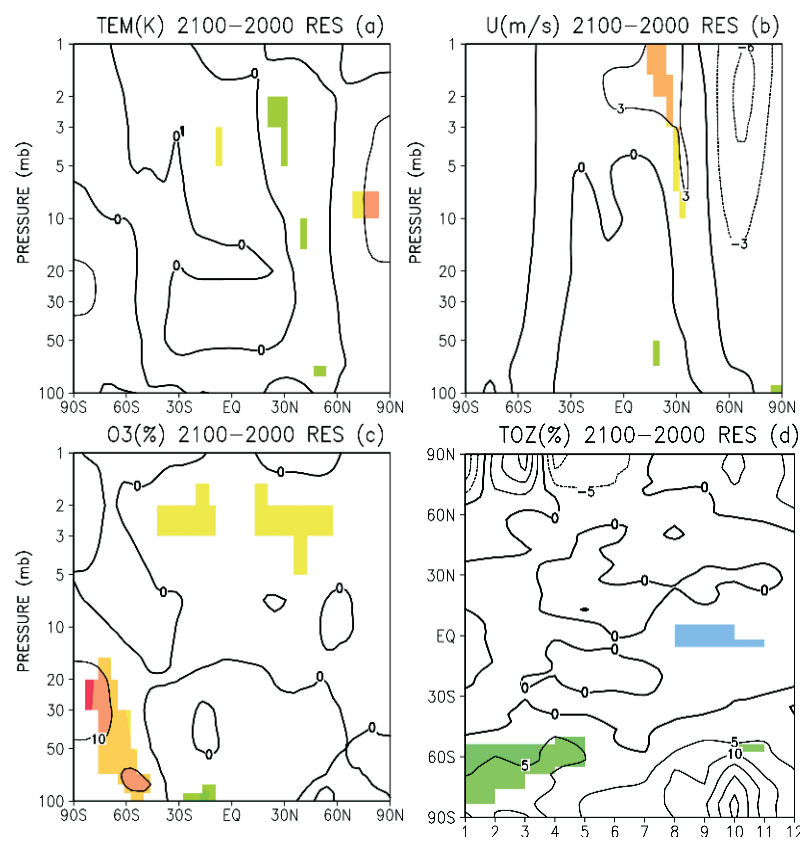

Fig. 5. Zonal and ensemble mean RES term (see the Eq. 1) for the changes of (a) annual mean temperature (K); (b) annual mean zonal wind $\left(\mathrm{m} \mathrm{s}^{-1}\right)$; (c) annual mean ozone mixing ratio (\%); (d) total column ozone (\%) from 2000 to 2100 . Color pattern indicates the regions where the changes are judged statistically significant at or better than $5 \%$ level.

A strong impact of the SST/SI on the ozone and circulation changes in the future has important implications for the analysis of the uncertainties in the total column ozone projections and their causes. Some differences between the results by different CCMs could be caused by the applied SST/SI rather than by the CCM's deficiencies. For example, Oman et al. (2010b) showed that CCM SOCOL simulates very strong acceleration of the BDC in the future and estimated the tropical residual vertical velocity increase from 1960 to 2100 in CCM SOCOL to be as high as $0.21 \mathrm{~mm} \mathrm{~s}^{-1}$, while this increase in the other CCMs is within $0.04-0.12 \mathrm{~mm} \mathrm{~s}^{-1}$. Strong increase of the BDC results in the strong cooling in the lower tropical stratosphere, pronounced tropical total column ozone depletion and faster total column ozone recovery over the middle and high latitudes. Our results suggest that such a strong increase of BDC intensity is caused by the applied SST changes from MPI-OM model, rather than simulated by the CCM in response to changing concentrations of GHG and ODS. To confirm this hypothesis, we have rerun FULL experiment for the years 2000 and 2100 using SST/SI acquired from the NCAR ESM output and found that the intensification of the tropical residual vertical velocity at $70 \mathrm{hPa}$ drops from $0.16 \mathrm{~mm} \mathrm{~s}^{-1}$ for the run driven by MPIOM SST to $0.1 \mathrm{~mm} \mathrm{~s}^{-1}$, which is in a reasonable agreement with other models (see Fig. 6 of Oman et al., 2010b).
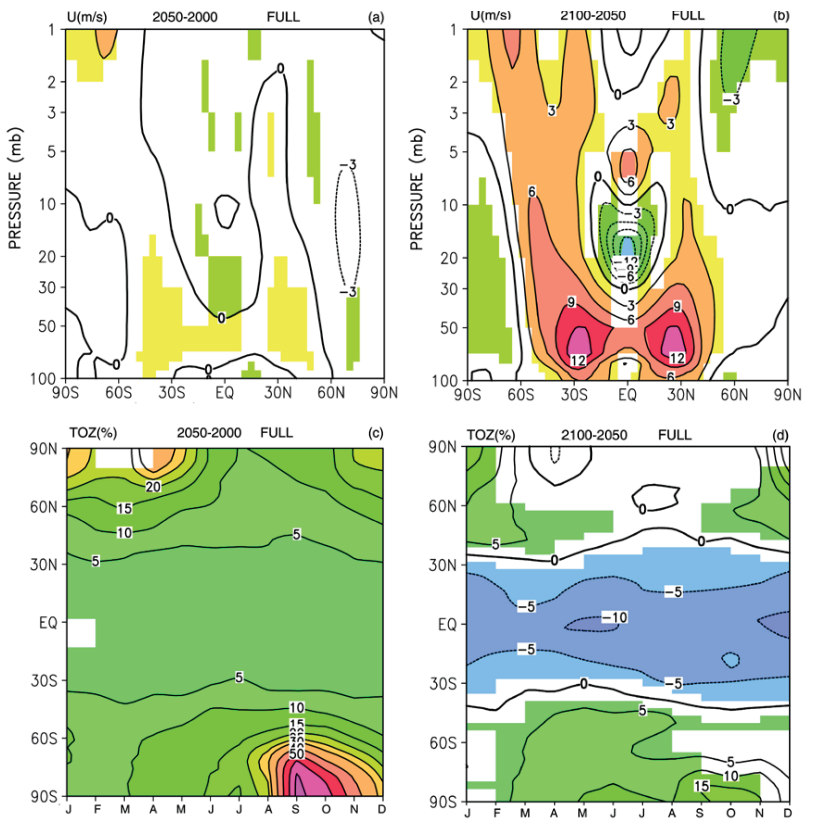

Fig. 6. Zonal and ensemble mean changes of annual mean zonal wind $\left(\mathrm{m} \mathrm{s}^{-1}\right)$ : (a) from 2000 to 2050; (b) from 2050 to 2100 and total column ozone (\%): (c) from 2000 to 2050; (d) from 2050 to 2100. Color pattern indicates the regions where the changes are judged statistically significant at or better than $5 \%$ level. Positive changes are shown in reddish colors while small or negative changes are colored in blue/violet.

\section{Summary and Discussion}

We have exploited chemistry-climate model SOCOL 2.0 to evaluate the ozone, temperature and circulation changes of the stratosphere over 21 st century due to main external forcings (GHG, ODS, SST/SI). Several $20 \mathrm{yr}$ long time slice ensemble runs have been performed with the CCM SOCOL using boundary conditions taken from IPCC A1B scenario for the GHG long-term evolution and the WMO A1 scenario for the century-long tendency of the ODS for the years 2000, 2050 and 2100. In these runs the SST/SI values are adopted from the model simulations with the atmosphere-ocean general circulation model (ECHAM5/MPIOM) driven also by the IPCC A1B scenario for the GHG long-term evolution (Table 1).

Analysis of the differences between the total effect (FULL) of all factors and the sum of the effects of the separate factors (GHG + ODS + SST/SI) leads us to the conclusion that the synergy of different factors is visible only in the southern polar region. In the other atmospheric regions the influence of this interaction does not exceed internal variability of the atmosphere and can be ignored. This fact confirms that the influence of considered factors can be evaluated with the applied set of experiments.

Comparison of the model experiments allows us to attribute the variability of the stratospheric ozone, temperature 
and circulation during the 21 st century to the main anthropogenic factors (GHG, ODS, SST/SI). The GHG factor provides the main part of cooling of the upper and middle stratosphere, especially over the southern polar region. The upper stratospheric westerlies are accelerated by the GHG factor mainly in the SH. All these atmospheric changes induced by GHG are responsible for up to $50 \%$ of the ozone increase in the upper stratosphere. GHG factor is also responsible for some ozone decline in the lower stratosphere in tropics and over the Antarctic area (Fig. 3b). The impact of the ODS consists of the ozone increase in the upper stratosphere (especially over the poles) and the vanishing of the Antarctic ozone "hole". These processes lead to additional heating of the upper stratosphere and the polar lower stratosphere in the $\mathrm{SH}$. The westerlies are decelerated in the polar-night jet region. Thus, the ODS is the main factor of the ozone layer recovery in the first half of the century especially in the extratropical latitudes of the both hemispheres. The forcing from SST leads to the tropical tropopause lifting, ozone depletion and cooling in the tropical lower stratosphere, acceleration of the subtropical jets and deceleration of the westerly flow in the northern stratosphere. It should be noted that these effects are more pronounced in the second half of the century. The SST/SI factor plays a dominant role in the atmospheric century-long changes in the lower stratosphere together with the ODS forcing. The long-term tendency of the total column ozone depends mainly on the ODS and SST/SI forcing. The ODS is the main driver of the total column ozone changes over the Antarctic and it is responsible for about $50 \%$ of these changes in the middle and high latitudes of the $\mathrm{NH}$ in the first half of the 21 st century. The SST/SI factor is the main contributor to the total column ozone depletion in the tropics and is responsible for a half of total column ozone increase over the northern extra-tropical latitudes. This effect of SST/SI factor appears mainly in the second half of the century. The influence of GHG forcing on the evolution of the ozone layer can be found in the upper stratosphere and does not contribute substantially to the relevant total column ozone changes.

We think that the choice of SST/SI should be done more carefully for the future model evaluation campaigns. If the goal of CCM simulations is a model intercomparison then CCMs should be run with the same SST/SI. If the goal of CCM simulations is to obtain future climate projections then the use of different SST/SI is beneficial because it allows better sampling of different sources of uncertainty. If both goals are desirable (which is usually the case), then (ideally) a separate set of CCM simulations should be planned in which all CCMs are run with the same forcing including the SST/SI. Furthermore, future model generations may include interactive ocean, which will likely have an effect on planning of model intercomparison. In this case, for more careful validation of the models and attribution of the future ozone trends and their uncertainties, the interactive treatment of the ocean can be recommended for the model validation against avail- able observations. This approach will provide more complete characterization of the model performance and allows better understanding of the future trends.

Acknowledgements. V. Z. and I. K. thank the Russian Foundation for Basic Research for funding this study (grant No. 11-05-00750a). The work of E. R. is partially supported by the Swiss National Science Foundation under grant CRSI122-130642 (FUPSOL). We appreciate the suggestions from A. Karpechko and three anonymous reviewers which allowed improving the manuscript.

Edited by: M. Dameris

\section{References}

Austin, J. and Wilson, R.: Sensitivity of polar ozone to sea surface temperatures and halogen amounts, J. Geophys. Res., 115, D18303, doi:10.1029/2009JD013292, 2010.

Austin, J., Struthers, H., Scinocca, J., Plummer, D. A., Akiyoshi, H., Baumgaertner, A. J. G., Bekki, S., Bodeker, G. E., Braesicke, P., Bruhl, C., Butchart, N., Chipperfield,M. P., Cugnet, D., Dameris, M., Dhomse, S., Frith, S., Garny, H., Gettelman, A., Hardiman, S. C., Jockel, P., Kinnison, D., Kubin, A., Lamarque, J. F., Langematz, U., Mancini, E., Marchand, M., Michou, M., Morgenstern, O., Nakamura, T., Nielsen, J. E., Pitari, G., Pyle, J., Rozanov, E., Shepherd, T. G., Shibata, K., Smale, D., Teyssedre, H., and Yamashita Y.: Chemistry-climate model simulations of spring Antarctic ozone, J. Geophys. Res., 115, D00M11, doi:10.1029/2009JD013577, 2010.

Calvo, N. and Garcia, R.: Wave forcing of the tropical upwelling in the lower stratosphere under increasing concentrations of greenhouse gases, J. Atmos. Sci., 66, 3184-3196, 2009.

Charlton-Perez, A. J., Hawkins, E., Eyring, V., Cionni, I., Bodeker, G. E., Kinnison, D. E., Akiyoshi, H., Frith, S. M., Garcia, R., Gettelman, A., Lamarque, J. F., Nakamura, T., Pawson, S., Yamashita, Y., Bekki, S., Braesicke, P., Chipperfield, M. P., Dhomse, S., Marchand, M., Mancini, E., Morgenstern, O., Pitari, G., Plummer, D., Pyle, J. A., Rozanov, E., Scinocca, J., Shibata, K., Shepherd, T. G., Tian, W., and Waugh, D. W.: The potential to narrow uncertainty in projections of stratospheric ozone over the 21st century, Atmos. Chem. Phys., 10, 94739486, doi:10.5194/acp-10-9473-2010, 2010.

Deckert, R. and Dameris, M.: Higher tropical SSTs strengthen the tropical upwelling via deep convection, Geophys. Res. Lett., 35, L10813, doi:10.1029/2008GL033719, 2008.

Egorova, T., Rozanov, E., Zubov, V., and Karol, I.: Model for Investigating Ozone Trends (MEZON), Izvestiya, Atmos. Ocean. Phys., 39, 277-292, 2003.

Egorova, T., Rozanov, E., Manzini, E., Haberreiter, M., Schmutz, W., Zubov, V., and Peter, T.: Chemical and dynamical response to the 11-year variability of the solar irradiance simulated with a chemistry-climate model, Geophys. Res. Lett., 31, L06119, doi:10.1029/2003GL019294, 2004.

Egorova, T., Rozanov, E., Zubov, V., Manzini, E., Schmutz, W., and Peter, T.: Chemistry-climate model SOCOL: a validation of the present-day climatology, Atmos. Chem. Phys., 5, 1557-1576, doi:10.5194/acp-5-1557-2005, 2005. 
Eyring, V., Butchart, N., Waugh, D., Akiyoshi, H., Austin, J., Bekki, S., Bodeker, G. E., Boville, B. A., Brühl, C., Chipperfield, M. P., Cordero, E., Dameris, M., Deushi, M., Fioletov, V. E., Frith, S. M., Garcia, R. R., Gettelman, A., Giorgetta, M. A., Grewe, V., Jourdain, L., Kinnison, D. E.,Mancini, E., Manzini, E., Marchand, M., Marsh, D. R., Nagashima, T., Newman, P. A., Nielsen, J. E., Pawson, S., Pitari, G., Plummer, D. A., Rozanov, E., Schraner, M., Shepherd, T. G., Shibata, K., Stolarski, R. S., Struthers, H., Tian, W., and Yoshiki, M.: Assessment of temperature, trace species, and ozone in chemistry-climate model simulation of the recent past, J. Geophys. Res., 111, D22308, doi:10.1029/2006JD007327, 2006.

Eyring, V., Waugh, D., Bodeker, G., Cordero, E., Akiyoshi,H., Austin, J., Beagley, S. R., Boville, B., Braesicke, P., Brühl, C., Butchart, N., Chipperfield, M. P., Dameris, M., Deckert, R., Deushi, M., Frith, S. M., Garcia, R. R., Gettelman, A., Giorgetta, M., Kinnison, D. E., Mancini, E., Manzini, E., Marsh D. R., Matthes, S., Nagashima, T., Newman, P. A., Nielsen, J. E., Pawson, S., Pitari, G., Plummer, D. A., Rozanov, E., Schraner, M., Scinocca, J. F., Semeniuk, K., Shepherd, T. G., Shibata, K., Steil, B., Stolarski, R., Tian, W., and Yoshiki, M.: Multimodel projections of stratospheric ozone in the 21 st century, J. Geophys. Res., 112, D16303, doi:10.1029/2006JD008332, 2007.

Eyring, V., Cionni, I., Bodeker, G. E., Charlton-Perez, A. J., Kinnison, D. E., Scinocca, J. F., Waugh, D. W., Akiyoshi, H., Bekki, S., Chipperfield, M. P., Dameris, M., Dhomse, S., Frith, S. M., Garny, H., Gettelman, A., Kubin, A., Langematz, U., Mancini, E., Marchand, M., Nakamura, T., Oman, L. D., Pawson, S., Pitari, G., Plummer, D. A., Rozanov, E., Shepherd, T. G., Shibata, K., Tian, W., Braesicke, P., Hardiman, S. C., Lamarque, J. F., Morgenstern, O., Pyle, J. A., Smale, D., and Yamashita, Y.: Multimodel assessment of stratospheric ozone return dates and ozone recovery in CCMVal-2 models, Atmos. Chem. Phys., 10, 94519472, doi:10.5194/acp-10-9451-2010, 2010.

Garcia, R. R. and Randel, W. J.: Acceleration of the Brewer-Dobson circulation due to increases in greenhouse gases, J. Atmos. Sci., 65, 2731-2739, 2008.

Gettelman, A., Hegglin, M., Son, S.-W., Kim, J., Fujiwara, M., Birner, T., Kremser, S., Rex, M., Anel, J. A., Akiyoshi, H., Austin, J., Bekki, S., Braesike, P., Brühl, C., Butchart, N., Chipperfield, M., Dameris, M., Dhomse, S., Garny, H., Hardiman, S. C., Jöuckel, P., Kinnison, D. E., Lamarque, J. F., Mancini, E., Marchand, M., Michou, M., Morgenstern, O., Pawson, S., Pitari, G., Plummer, D., Pyle, J. A., Rozanov, E., Scinocca, J., Shepherd, T. G., Shibata, K., Smale, D., Teyssdre, H., and Tian, W.: Multimodel assessment of the upper troposphere and lower stratosphere: Tropics and global trends, J. Geophys. Res., 115, D00M08, doi:10.1029/2009JD013638, 2010.

IPCC, 2001: Climate Change 2001: The Scientific Basis, Contribution of Working Group I to the Third Assessment Report of the Intergovernmental Panel on Climate Change, edited by: Houghton, J. T., Ding, Y., Griggs, D. J. , Noguer, M., van der Linden, P. J. , Dai, X., Maskell, K., and Johnson, C. A., Cambridge University Press, Cambridge, United Kingdom and New York, NY, USA, 881 pp., 2001

IPCC, 2007: Climate Change 2001: The Scientific Basis. Contribution of Working Group I to the Fourth Assessment Report of the Intergovernmental Panel on Climate Change, edited by: Solomon, S., Qin, D., Manning, M., Chen, Z., Marquis, M., Av- eryt, K. B., Tignor, M., and Miller, H. L., Cambridge University Press, Cambridge, United Kingdom and New York, NY, USA, 996 pp., 2007.

Jungclaus, J., Keenlyside, N., Botzet, M., Haak, H., Luo, J.-J., Latif, M., Marotzke, J., Mikolajewicz, U., and Roeckner, E.: Ocean circulation and tropical variability in the coupled model ECHAM5/MPI-OM, J. Climate, 19, 3952-3972, 2006.

Kodama, C., Iwasaki, T., Shibata, K., and Yukimoto, S.: Changes in the stratospheric mean meridional circulation due to increased $\mathrm{CO}_{2}$ : Radiation and sea surface temperature-induced effects, J. Geophys. Res., 112, D16103, doi:10.1029/2006JD008219, 2007.

Li, F., Stolarski, R. S., and Newman, P. A.: Stratospheric ozone in the post-CFC era, Atmos. Chem. Phys., 9, 2207-2213, doi:10.5194/acp-9-2207-2009, 2009.

Manzini, E., McFarlane, N. A., and McLandress, C.: Impact of the Doppler Spread parameterization on the simulation of the middle atmosphere circulation using the MA/ECHAM4 general circulation model, J. Geophys. Res., 102, 25751-25762, 1997.

McLandress, C. and Shepherd, T., Simulated anthropogenic changes in the Brewer-Dobson circulation, including its extension to high latitudes, J. Climate, 22, 1516-1540, 2009.

Morgenstern, O., Giorgetta, M., Shibata, K., Eyring, V., Waugh, D. W., Shepherd, T. G., Akiyoshi, H., Austin, J., Baumgaertner, A. J. G., Bekki, S., Braesicke, P., Brühl, C., Chipperfield, M. P., Cugnet, D., Dameris, M., Dhomse, S., Frith, S. M., Garny, H., Gettelman, A., Hardiman, S. C., Hegglin, M. I., Kinnison, D. E., Lamarque, J.-F., Mancini, E., Manzini, E., Marchand, M., Michou, M., Nakamura, T., Nielsen, J. E., Pitari, G., Plummer, D. A., Rozanov, E., Scinocca, J. F., Smale, D., Teyssedre, H., Toohey, M., Tian, W., and Yamashita, Y.: Review of the formulation of present-generation stratospheric chemistry-climate models and associated external forcings, J. Geophys. Res., 115, D00M02, doi:10.1029/2009JD013728, 2010.

Olsen, M. A., Schoeberl, M., and Nielsen, J.: Response of stratospheric circulation and stratosphere-troposphere exchange to changing sea surface temperatures, J. Geophys. Res., 112, D16104, doi:10.1029/2006JD008012, 2007.

Oman, L., Waugh, D., Kawa, S., Stolarski, R., Douglass, A., and Newman, P.: Mechanisms and feedbacks causing changes in upper stratospheric ozone in the 21 st century, J. Geophys. Res., 115, D05303, doi:10.1029/2009JD012397, 2010a.

Oman, L. D., Plummer, D., Waugh, D., Austin, J., Scinocca, J. F., Douglass, A. R., Salawitch, R. J., Canty, T., Akiyoshi, H., Bekki, S., Braesicke, P., Butchard, N., Chipperfield, M. P., Cugnet, D., Dhomse, S., Eyring, V., Frith, S., Hardiman, S. C., Kinnison, D. E., Lamarque, J.-F., Mancini, E., Marchand, M., Michou, M., Morgenstern, O., Nakamura, T., Nielsen, J.E., Olivié, D., Pitari, G., Pyle, J., Rozanov, E., Shepherd, T. G., Shibata, K., Stolyarski, R. S., Teyssèdre, H., Tian, W., Yamashita, Y., and Ziemke, J. R.: Multimodel assessment of the factors driving stratospheric ozone evolution over the 21 st century, J. Geophys. Res., 115, D24306, doi:10.1029/2010JD014362, 2010 b.

Rind, D., Lerner, J., Perwitz, J., McLinden, C., and Prather, M.: Sensitivity of tracer transports and stratospheric ozone to seasurface temperature patterns in the doubled $\mathrm{CO}_{2}$ climate, J. Geophys. Res., 107, 4800, doi:10.1029/2002JD002483, 2002.

Schraner, M., Rozanov, E., Schnadt Poberaj, C., Kenzelmann, P., Fischer, A. M., Zubov, V., Luo, B. P., Hoyle, C. R., Egorova, T., Fueglistaler, S., Brönnimann, S., Schmutz, W., and Peter, T.: 
Technical Note: Chemistry-climate model SOCOL: version 2.0 with improved transport and chemistry/microphysics schemes, Atmos. Chem. Phys., 8, 5957-5974, doi:10.5194/acp-8-59572008, 2008.

Shepherd, T. and McLandress, C.: A robust mechanism for strengthening of the Brewer-Dobson circulation under climate change: Critical-layer control of subtropical wave breaking, J. Atmos. Sci., 68, 784-797, 2011.

SPARC Report on the Evaluation of Chemistry-Climate Models, edited by: Eyring, V., Shepherd, T. G., and Waugh, D. W., SPARC Report No. 5, WCRP-132, WMO/TD-No.1526, 2010.

Strahan, S., Douglass, A., Stolarski, E., Akiyoshi, H., Bekki, S., Braesicke, P., Butchart, N., Chipperfield, M. P., Cugnet, D., Dhomse, S., Frith, S.M., Gettelman, A., Hardiman, S. C., Kinnison, D. E., Lamarque, J. F., Mancini, E., Marchand, M., Michou, M., Morgenstern, O., Nakamura, T., Olivie, D., Pawson, S., Pitari, G., Plummer, D. A., Pyle, J. A., Scinocca, J. F., Shepherd, T. G., Shibata, K., Smale, D., Teyssedre, H., Tian. W, and Yamashita, Y.: Using transport diagnostics to understand chemistry climate model ozone simulations, J. Geophys. Res., 116, D17302, doi:10.1029/2010JD015360, 2011.

von Storch, H. and Zwiers, F.: Statistical Analysis in Climate Research, Cambridge Univ. Press, 424 pp., 2001.
WMO, Scientific Assessment of Ozone Depletion: 2006, Global Ozone Research and Monitoring Project-Rep. 50, World Meteorological Organization, Geneva, Switzerland, 572 pp., 2007.

WMO, Scientific Assessment of Ozone Depletion: 2010, Global Ozone Research and Monitoring Project-Rep. 52, World Meteorological Organization, Geneva, Switzerland, 442 pp., 2011.

Zubov, V., Rozanov, E., and Schlesinger, M.: Hybrid scheme for 3dimensional advective transport, Mon. Weather Rev., 27, 13351346, 1999.

Zubov, V., Rozanov, E., Shirochkov, A., Makarova, L., Egorova, T., Kiselev, A., Ozolin, Y., Karol, I., and Schmutz, W.: Modeling of Joule heating influence on the circulation and ozone concentration in the middle atmosphere, J. Atmos. Sol.-Terr. Phy., 67, 155-162, 2005.

Zubov, V., Rozanov, E., Shirochkov, A., Makarova, L., Egorova, T., Kiselev, A., Ozolin, Y., Karol, I., and Schmutz, W.: Influence of Solar Wind on Ozone and Circulation in the Middle Atmosphere: A Model Study, Dokl. Earth Sci., 408, 595-598, doi:10.1134/S1028334X06040192, 2006.

Zubov, V., Rozanov, E., Rozanova, I., Egorova, T., Kiselev, A., Karol, I., and Schmutz, W.: Modeling the global ozone and atmospheric dynamics changes for 21 st century with the chemistryclimate model SOCOL, Izvestiya AN, Atmos. Ocean. Phys., 47, 301-312, doi:10.1134/s0001433811030121, 2011. 